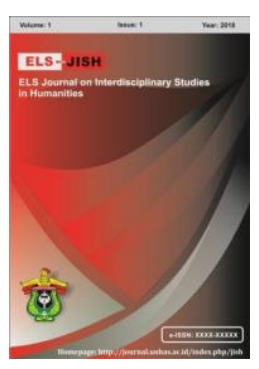

ELS-JISH

ELS Journal on Interdisciplinary Studies on Humanities

Volume 3 Issue 1, 2020

ISSN (print) : 2621-0843

ISSN (online) : 2621-0835

Homepage : http://journal.unhas.ac.id/index.php/jish

\title{
Development of Linguistic Intelligence Instruments for Elementary Schools Student
}

\author{
Otang Kurniaman ${ }^{1}$, Dea Sinta Maharani ${ }^{2}$, Eddy Noviana ${ }^{3}$, Nofrico Afendi ${ }^{4}$ \\ 1 otang.kurniaman@lecturer.unri.ac.id
}

\begin{abstract}
This research method is a 4-D model that has stages which include: 1) defining, 2) design, 3) development and 4) dissemination. Respondents tested a limited instrument involving 21 fourth grade students in elementary school. The results of this study obtained an assessment from experts in the validation of linguistic intelligence instruments with an average of 3.5 with worthiness of 86.75 in the very feasible category. The next activity is the stage of developing instruments to assess linguistic intelligence and then a limited trial of 21 students with the results of linguistic intelligence obtained by students 1 (4.8\%) female students who have very high linguistic intelligence, 7 (33.33\%) students who linguistic intelligence with a high category, 11 (52.4\%) students who have linguistic intelligence with a high enough category and 2 (9.5\%) students who have linguistic intelligence with a low category. It can be concluded that the instrument for assessing linguistic intelligence in elementary school students can be used on a broad scale.
\end{abstract}

Keywords: Linguistic Intelligence, Instruments, Elementary Schools Student.

How to cite: Kurniaman, O., et al. (2020). Development of Linguistic Intelligence Instruments for Elementary Schools Student. ELS Journal on Interdisciplinary Studies in Humanities, 3(1), 85-96. DOI: http://dx.doi.org/10.34050/els-jish.v3i1.8966

\section{Introduction}

Since being born someone already has intelligence, but still depends on others to develop it. This intelligence will continue to grow in line with the increasing age of the child and the experiences that go through with the interaction between the environment (Islam, et al, 2019). The intelligence of each human being is different from one another. This different intelligence is then known and grouped into multiple intelligences (Azimah \& Kurniaman, 2019). Douglas (in Sari, Palangngan, Mulyaningsih, Samritin, \& Rahman, 2019) found that teaching and learning environment field possibly varied in the form of language. Hence, intelligence form of a child, for example how to speak, counts on the environment. Linguistic intelligence emphasizes the ability of children to use language as a simple symbol and medium of communication intermediaries. Primary school children have the ability to assemble an understanding or information into systematic ideas written and able to attract the attention of the surrounding environment (Hermita, Hamid, Adiputra \& 
Samsudin , 2017). The ability of children who have high intelligence will be seen from the ability to solve problems faced in life, skills to develop new problems, and skills to make things or do something useful in life (Gardner, 2003). Language intelligence is highly valued in the modern world as it is today because people tend to judge others by the way they speak and write. A person's first view will be formed when the person speaks (Lazaer, 1995).

The linguistic intelligence in elementary school contains the indicators to be studied, namely the students' ability to listen, speak, read, and writing skills by developing assessment instruments that will be used by the teacher to assess their students by only using this instrument and being able to judge for themselves. A teacher must be able to develop students' linguistic intelligence optimally as a capital for themselves in solving existing problems, with a lot of reading that greatly influences cognitive intelligence (Zulfah \& Senam, 2018). Reading and listening play an important role in learning Indonesian in the curriculum in elementary schools, based on students must be able to master language skills that have four skills that are part of linguistic intelligence. However, acquiring reading and listening skills is not easy for students because this is related to understanding as to the main goal of reading and listening for Indonesian students (Magfirah, 2018). The ability to read and write at the elementary school level is part of language skills. Language is a means to obtain knowledge and at the same time a part of the culture, as well as a means of communication. Language boundaries are world boundaries. In elementary school, Reading plays an important role in improving basic abilities in all fields of science, which is a milestone in developing the intellect and potential of children. Reading is a basic skill that every human being must-have. This skill cannot be separated from human life (Kurniaman et al., 2018). Therefore, reading skills are basic skills that are very important for human life. All that is obtained from reading activities will enable the person to be able to enhance his thinking power, sharpen his views, and broaden his horizons (Kurniaman \& Noviana, 2016). The potential of students in mastering linguistic intelligence is taught in the process of learning, communicating, and acting in the environment (Mikhailova, 2018).

To measure the linguistic intelligence possessed by students, an assessment instrument is needed that can measure the intelligence. Assessment instruments are assessment tools or evaluation tools which in this case are used to collect assessments related to linguistic intelligence. The assessment instrument is a very important part of measuring the level of intelligence of students so that the assessment instruments made must be by the objectives to be achieved by the assessment. The instrument of linguistic intelligence assessment can be made with the form of tests or non-tests that will be adjusted to the aspects of linguistic intelligence to be measured. By making the right assessment instrument, the measurement of the level of linguistic intelligence possessed by students is more accurate. 


\section{Method}

The development model used in the development of this assessment instrument is the 4-D model proposed by Thiagarajan and Semmel with four stages consisting of Define, Design, Development, and Disseminate (Sugiyono, 2017). The purpose of this research is to develop a linguistic intelligence assessment instrument that is feasible for use in elementary schools. The feasibility of the product of this linguistic intelligence assessment instrument is measured by validators who are experts in the field of linguistics and linguistics and by practitioners of product users (Kurniaman et al., 2018). The linguistic intelligence instrument was developed using a 4-D model developed by Thiagarajan (1974) which included: 1) defining, 2) design, 3) development and 4) dissemination. Respondents tested a limited instrument that involved 21 fourth grade students in elementary school.

The flow of development of previous linguistic intelligence instruments can be explained as follows:

\subsection{Define Stage}

The defining stage is an activity carried out to define product development requirements. In other models, the definition phase is also called the analysis of the needs needed to analyze existing needs so that it can be a reason for developing the product. In this study, the definition phase is done by:

\section{a. Field Study}

The researcher began this research by conducting field studies by analyzing teacher and school knowledge about the importance of students to have linguistic intelligence. But it turns out that both the teacher and the school are still not aware of the existence of linguistic intelligence for students. Departing from this problem, researchers made research by developing instruments of a linguistic intelligence assessment that can be used to measure students' linguistic intelligence.

\section{b. Study of literature}

After potential problems are obtained through the process of field analysis, then the literature analysis activities related to the products to be developed are then carried out. Literature studies are conducted to collect information that can be used as material for product planning that will be developed to overcome emerging problems (Sugiyono, 2017). In this activity the researcher collects information related to this research, among others: 1) Analysis of components of linguistic intelligence; 2) Analysis of aspects of linguistic intelligence, and 3) Analysis of research objectives.

\subsection{Design Stage}

The design stage is a stage that is carried out to design a product that is tailored to the problems found in the defining stage. At this design stage, researchers designed product assessment instruments to measure linguistic intelligence. The activities carried out at this design stage are: a) develop a linguistic intelligence test; b) develop instruments for assessing linguistic intelligence; and c) adjust assessment rubrics with components and aspects of 
linguistic intelligence. The products produced at this design stage are called draft I instrument for assessing linguistic intelligence.

\subsection{Development Stage}

The development stage is the stage of developing a product that has been designed in the previous stage, in the form of an assessment instrument called draft I. At this stage, the product of the draft I results from the previous stages are validated by experts and practitioners to see the feasibility of the product. In this study, the validator consisted of linguists, linguists and 3 elementary school teachers as practitioners and experts in field users who would use the products developed. At this stage, the validator will assess the initial product (draft I) and provide criticism which then errors in the draft I will be analyzed and revised based on suggestions from the validator so that it will produce draft II. Furthermore, draft II will be validated again by the validator and after being analyzed and revised.

After a series of product validation stages, then the draft II of the product evaluation instrument that has been revised according to the validator's suggestion will be conducted a limited trial of 21 fourth grade students at Muhammadiyah 6 Pekanbaru elementary school to see whether the product developed can measure the linguistic intelligence possessed by students.

\subsection{Disseminate Stage}

Disseminate stage is the stage of product dissemination that has been developed by researchers. In this stage, the researcher socializes the product of linguistic intelligence assessment instruments to 10 teachers consisting of class I - class VI teachers. After the product of the linguistic intelligence assessment instrument is socialized to the teacher as a practitioner who will use this product, the researcher provides a questionnaire for the teacher's response to seeing the teacher's response more broadly to the product that has been developed by the researcher.

To assess the feasibility and advice of the validator for the designed linguistic intelligence assessment instrument products. The validation sheet in this study includes 6 components that will be assessed by the validator. The grid of validation sheets can be seen in the following table:

Table 1. Grid of Validation Sheets

\begin{tabular}{clcc}
\hline No & \multicolumn{1}{c}{ Component of Assessment } & Code & $\begin{array}{c}\text { Number of } \\
\text { Statements }\end{array}$ \\
\hline $\mathbf{1}$ & Test equipment & $\mathrm{K} 1$ & 3 \\
\hline $\mathbf{2}$ & $\begin{array}{l}\text { Overall assessment of linguistic } \\
\text { intelligence instruments }\end{array}$ & $\mathrm{K} 2$ & 5 \\
\hline $\mathbf{3}$ & $\begin{array}{l}\text { The linguistic intelligence instrument } \\
\text { reads aspects }\end{array}$ & $\mathrm{K} 3$ & 7 \\
\hline $\mathbf{4}$ & $\begin{array}{l}\text { The linguistic intelligence instrument } \\
\text { write aspects }\end{array}$ & $\mathrm{K} 4$ & 7 \\
\hline $\mathbf{5}$ & $\begin{array}{l}\text { The linguistic intelligence instrument } \\
\text { speak aspect }\end{array}$ & $\mathrm{K} 5$ & 7 \\
\hline $\mathbf{6}$ & $\begin{array}{l}\text { The linguistic intelligence instrument } \\
\text { listening aspect }\end{array}$ & $\mathrm{K} 6$ & 8 \\
\hline
\end{tabular}


Data collection techniques are ways that researchers use to obtain data. In this study, the data was obtained by giving a questionnaire to the validator, namely the questionnaire validation of linguistic intelligence instruments and providing questionnaires to the teacher on limited trial activities. The data obtained is then analyzed and processed by the researcher so that the results of data analysis are obtained. The data in this study were then analyzed using descriptive analysis techniques that aimed to describe the results of validation given by 5 validators after the validation stage. The validation aspects assessed by the validator are made in the form of a Likert Scale with a score of 1-4. This scale gives flexibility to each validator to assess the linguistic intelligence assessment instrument developed. The product validity of the linguistic intelligence instrument is determined through the average score given by the validator (Kurniaman \& Zufriady, 2019). Rating categories are shown in the following table:

\begin{tabular}{cc}
$\begin{array}{c}\text { Table 2. Category } \\
\text { Assessment }\end{array}$ & Category \\
Score & \\
\hline 4 & strongly agree \\
3 & agree \\
2 & disagree \\
1 & strongly disagree
\end{tabular}
namely:

The results of validity are calculated using the average score formula,

$$
\text { percentage }=\frac{\text { score obtained }}{\text { maximum score }} \times 100 \%
$$

The validity criteria can be seen in the following table:

Table 3. Validity Criteria Intervals

\begin{tabular}{cc}
\hline $\begin{array}{c}\text { Average Score } \\
\text { Interval }\end{array}$ & Category \\
\hline $81-100$ & very decent \\
$61-80$ & decent \\
$41-60$ & deceant enough \\
$21-40$ & not decent \\
$0-20$ & very not decent \\
\hline
\end{tabular}

The results of a limited trial of linguistic intelligence assessment products for fourth-grade students were carried out by conducting a series of tests consisting of reading skills tests, writing skills tests, speaking skills tests and listening skills tests can be calculated using the average score formula, namely:

Information :

$$
\mathrm{x}=\Sigma(\mathrm{a})+\Sigma(\mathrm{b})+\Sigma(\mathrm{c})+\Sigma(d)
$$

$X \quad$ : Total of linguistic intelligence

$\Sigma(a)$ : Total of values for reading skills

$\Sigma(b)$ : Total of values of writing skills

$\Sigma(c)$ : Total of values of speaking skills

$\Sigma(d)$ : Total of values of listening skills 
After obtaining all the values of each skill in linguistic intelligence, the values can be configured into the following categories.

Table 4. Interval of Linguistic Intelligence Criteria

\begin{tabular}{cc}
\hline $\begin{array}{c}\text { Score Average } \\
\text { Interval }\end{array}$ & Category \\
\hline $90-100$ & very high \\
\hline $76-89$ & high \\
\hline $51-75$ & high enough \\
\hline $26-50$ & not high \\
\hline $0-25$ & very not high \\
\hline
\end{tabular}

After the product validation of the linguistic intelligence assessment instrument and limited trials on fourth-grade students, the product was then disseminated to 10 teachers to see how the teacher responded as a practitioner in using the products developed. The response results data will be analyzed according to the assessment guidelines that have been developed. The following are the assessment categories contained in the teacher response questionnaire.

Table 5. Questionnaire Assessment Category Teacher Response

\begin{tabular}{cc}
\hline Assessment Score & Category \\
\hline 4 & strongly agree \\
3 & agree \\
2 & disagree \\
1 & strongly \\
& disagree \\
\hline
\end{tabular}

The results of validity are calculated using the average score formula, namely: percentage $=\frac{\text { score obtained }}{\text { maximum score }} \times 100 \%$

The response criteria can be seen in the following table:

Table 6. Interval Response Criteria

\begin{tabular}{cc}
\hline $\begin{array}{c}\text { Average Score } \\
\text { Interval }\end{array}$ & Category \\
\hline $81-100 \%$ & very practical \\
$61-80 \%$ & practical \\
$41-60 \%$ & practical enough \\
$21-40 \%$ & not practical \\
$0-20$ & very not practical \\
\hline
\end{tabular}

\section{RESULTS}

At this stage, the product of the linguistic intelligence assessment instrument (draft I) that has been designed is then validated to see the feasibility of the product. This validation was carried out by 5 experts consisting of 1 linguistics lecturer, 1 linguist expert, 2 field experts (elementary school Indonesian teacher at An Namiroh 4 Elementary School Pekanbaru) and 1 field expert (SD An Namiroh 4 Pekanbaru class teacher). The validator above then gives an assessment in the form of criticism, suggestions and also direction to the product of the assessment instrument that has been designed (draft I) in accordance with the expertise field of each validator by filling in the validation 
sheet. The results of the product validation of the linguistic intelligence assessment instrument are described in the following table:

Table 7. Data on Instrument Validation Assessment from Experts

\begin{tabular}{clccc}
\hline No & \multicolumn{1}{c}{ Component } & Average & $\begin{array}{c}\text { Value of } \\
\text { Decent }\end{array}$ & Category \\
\hline 1. & $\begin{array}{l}\text { Reading Skills } \\
\text { Assessment } \\
\text { Instrument }\end{array}$ & 3.6 & 89 & very decent \\
\hline 2. & $\begin{array}{l}\text { Writing Skills } \\
\text { Assessment } \\
\text { Instrument }\end{array}$ & 3.4 & 85 & very decent \\
\hline 3. & $\begin{array}{l}\text { Speaking Skills } \\
\text { Assessment } \\
\text { Instrument }\end{array}$ & 3.6 & 89 & very decent \\
\hline 4. $\begin{array}{l}\text { Listening Skills } \\
\text { Assessment } \\
\text { Instrument }\end{array}$ & 3.4 & 84 & very decent \\
\hline$\quad$ Average & 3.5 & $\mathbf{8 6 . 7 5}$ & very decent \\
\hline
\end{tabular}

The results of expert assessments of the instrument for assessing linguistic intelligence in elementary schools from several experts assessed the results in accordance with the indicators of the development of linguistic intelligence instruments on indicators of assessment of reading skills with an average of 3.6 with very decent categories (89), indicators of writing skills assessment 3.4 with a very decent category (85), indicators of speaking skills assessment with an average of 3.6 with a very decent category (89), and indicators of listening skills assessment with an average of 3.4 with a very feasible category (84). Validation data on instruments that have been developed are feasible to use in measuring linguistic intelligence with an overall average of 3.5 with a feasibility value of 86.75 with a very feasible category. The next activity after validation by experts in the development stage is a trial. This limited trial was carried out in class IV of Muhammadiyah 6 Pekanbaru Elementary School with the aim to see whether the product developed by the researcher was able to measure the level of linguistic intelligence of the fourthgrade students at Muhammadiyah 6 Pekanbaru Elementary School. This limited trial activity was conducted for 2 meetings with a total of 21 students. In accordance with the tests and assessment instruments developed, this trial activity begins with a reading test by providing prepared reading material which is then followed by a test of writing a speech, a speaking test and ending with a listening test. The results of the testing of test kits and instruments of assessment of linguistic intelligence in class IV of Muhammadiyah 6 Pekanbaru Elementary School can be seen in the following table: 
Table 8. Results of Linguistic Intelligence IV Grade Students of Muhammadiyah 6 Elementary School Pekanbaru in Limited Trials

\begin{tabular}{ccccccc}
\hline Code & $\begin{array}{c}\text { Readin } \\
\text { g Skills }\end{array}$ & $\begin{array}{c}\text { Writin } \\
\text { g } \\
\text { Skills }\end{array}$ & $\begin{array}{c}\text { Speakin } \\
\text { g Skills }\end{array}$ & $\begin{array}{c}\text { Listenin } \\
\text { g Skills }\end{array}$ & Total & Category \\
\hline D1 & 18.75 & 17.5 & 17.13 & 16.45 & 69.83 & high enough \\
\hline D2 & 19 & 14 & 14.50 & 14.60 & 62.1 & high enough \\
\hline D3 & 20 & 20 & 19.25 & 18.75 & 78 & high \\
\hline D4 & 21 & 18.75 & 20.38 & 20.60 & 80.73 & high \\
\hline D5 & 22.5 & 22.25 & 21.75 & 20.85 & 87.35 & high \\
\hline D6 & 11.5 & 14 & 11.75 & 14.60 & 51.85 & high enough \\
\hline D7 & 22.75 & 19.5 & 17.25 & 18.50 & 78 & high \\
\hline D8 & 12.75 & 14 & 12.75 & 14.35 & 53.85 & high enough \\
\hline D9 & 10.25 & 11 & 11.13 & 14.10 & 46.48 & high enough \\
\hline D10 & 14.75 & 14.5 & 15.38 & 14.35 & 58.98 & high enough \\
\hline D11 & 15.25 & 15.25 & 18.13 & 17.30 & 65.93 & high enough \\
\hline D12 & 21.25 & 16.5 & 17.25 & 16.90 & 71.90 & high enough \\
\hline D13 & 17.75 & 14.75 & 15.88 & 14.60 & 62.98 & high enough \\
\hline D14 & 22.75 & 22.25 & 22.25 & 21.10 & 88.35 & high \\
\hline D15 & 10 & 12.5 & 13.25 & 14.35 & 50.10 & not high \\
\hline D16 & 23.75 & 23.5 & 23.13 & 21.55 & 91.93 & very high \\
\hline D17 & 20 & 17.25 & 20.25 & 16.90 & 74.40 & high enough \\
\hline D18 & 15.25 & 14 & 16.25 & 14.85 & 60.35 & high enough \\
\hline D19 & 21 & 18.5 & 20.50 & 19.00 & 79 & high \\
\hline D20 & 10.25 & 14.5 & 13.88 & 15.95 & 54.58 & high enough \\
\hline D21 & 21.5 & 19.5 & 19.88 & 17.15 & 78.03 & high \\
\hline Bas & & & & & & \\
\hline
\end{tabular}

Based on the tests that have been undertaken by fourth grade students in Muhammadiyah 6 Pekanbaru Elementary School which consist of reading skills tests, writing skills tests, speaking skills tests and listening skills tests whose results have been calculated in accordance with the linguistic intelligence assessment instruments that have been developed by researchers the average level of linguistic intelligence in fourth grade students at SD Muhammadiyah 6 Pekanbaru is 1 (4.8\%) female students have very high linguistic intelligence, 7 $(33.33 \%)$ students have high linguistic intelligence, $11(52.4 \%)$ people who have linguistic intelligence with a high enough category and $2(9.5 \%)$ students who have linguistic intelligence with a category that is not high.

The last stage in this development is the Disseminate stage, which is the stage of product dissemination that researchers have developed after going through the stages of validation and trial. This stage of dissemination is the stage of disseminating products to teachers as practitioners who will use the assessment instrument products that have been developed. At this stage, the researcher will provide a questionnaire response to see how the teacher's response as a practitioner of the product of the linguistic intelligence assessment instrument has been developed. The researcher socialized the product of the assessment instrument to 10 homeroom teachers in Muhammadiyah 6 Elementary School Pekanbaru. The results of the teacher's response to the product of the linguistic intelligence assessment instrument can be seen in the following table: 
Otang Kurniaman. 3(1): 85-96

Table 9. Results of Teacher Responses to Dissemination

\begin{tabular}{|c|c|c|c|c|}
\hline No & Statement & $\begin{array}{l}\text { Total } \\
\text { score }\end{array}$ & $\begin{array}{l}\text { Response } \\
\text { Value (\%) }\end{array}$ & Category \\
\hline 1 & $\begin{array}{l}\text { The language used in the } \\
\text { assessment instrument is clear } \\
\text { and easy for me to understand }\end{array}$ & 37 & $93 \%$ & $\begin{array}{c}\text { very } \\
\text { practical }\end{array}$ \\
\hline 2 & $\begin{array}{l}\text { The assessment instrument } \\
\text { developed is easy to understand } \\
\text { and easy to use }\end{array}$ & 30 & $80 \%$ & $\begin{array}{c}\text { very } \\
\text { practical }\end{array}$ \\
\hline 3 & $\begin{array}{l}\text { Scoring in assessment instruments } \\
\text { is clear and easy for me to } \\
\text { understand }\end{array}$ & 35 & $88 \%$ & $\begin{array}{c}\text { very } \\
\text { practical }\end{array}$ \\
\hline 4 & $\begin{array}{l}\text { The assessment instrument } \\
\text { developed was able to measure } \\
\text { the level of linguistic intelligence of } \\
\text { students }\end{array}$ & 34 & $85 \%$ & $\begin{array}{c}\text { very } \\
\text { practical }\end{array}$ \\
\hline 5 & $\begin{array}{l}\text { The assessment instrument } \\
\text { developed can be used to } \\
\text { measure the linguistic intelligence } \\
\text { of high-class students in } \\
\text { elementary school }\end{array}$ & 37 & $93 \%$ & $\begin{array}{c}\text { very } \\
\text { practical }\end{array}$ \\
\hline 6 & $\begin{array}{l}\text { Explanation of the score } \\
\text { calculation formula in each skill is } \\
\text { clear and easy for me to } \\
\text { understand }\end{array}$ & 36 & $90 \%$ & $\begin{array}{c}\text { very } \\
\text { practical }\end{array}$ \\
\hline 7 & $\begin{array}{l}\text { The explanation of the overall } \\
\text { linguistic intelligence score } \\
\text { calculation formula is clear and } \\
\text { easy for me to understand }\end{array}$ & 37 & $93 \%$ & $\begin{array}{c}\text { very } \\
\text { practical }\end{array}$ \\
\hline 8 & $\begin{array}{l}\text { Explanation of the description of } \\
\text { each assessment score of } \\
\text { linguistic intelligence is clear and } \\
\text { easy for me to understand }\end{array}$ & 33 & $83 \%$ & $\begin{array}{c}\text { very } \\
\text { practical }\end{array}$ \\
\hline & Average & & $88 \%$ & $\begin{array}{c}\text { very } \\
\text { practical }\end{array}$ \\
\hline
\end{tabular}

\section{DISCUSSIONS}

This research is a type of development research (research \& development) with the aim of research to develop linguistic intelligence assessment instrument products and test the feasibility of these products that are used to measure linguistic intelligence of elementary school students. Development of this instrument for school use to be used with the needs of students in measuring linguistic intelligence to find out what disorders exist in students so that teachers are easy to detect and provide learning in accordance with students' problems (Angelka \& Goran, 2018). The types of problems in linguistic intelligence in learning are often unknown to the teacher so that language skills that must be optimally developed can experience fatal difficulties that result in students lacking confidence in learning languages so that linguistic intelligence is so low that a very important intelligence instrument is made (Damaianti, 2017). To understand the concept of assessing the linguistic intelligence of classroom teachers in primary schools must be able to evaluate 
student learning and language use in a few weeks to see the developments that arise in students to monitor each student in-class activities. This kind of evaluation is useful for monitoring progress in each student's linguistic intelligence in a fairly informal way (Douglas, 2018).

Among the various efforts to understand complex cognitive operations such as reading skills, writing skills, listening skills, and speaking skills, the approach is characterized by extensive collection and analysis of linguistic intelligence data sets that are theoretically hypothesized, so as to show students' individual abilities and finally providing a more balanced one for pedagogic language and assessment (Yamashita \& Shiotsu, 2015). The success of learning in schools is measured in reading, writing, listening and speaking skills, thus becoming an important concern for teachers in academic success (Chong, 2017; Susanti, 2018; Kurniaman \& SB Sismulyasih, 2019). Linguistic intelligence develops in accordance with cognitive intelligence acquired by students at birth which will develop naturally and be influenced by the environment as the most influential school because students will always interact with their friends so that they share the ability to speak in accordance with the child's level (Kafryawan et al., 2018). Then it can be concluded that the linguistic intelligence instrument is very important to be made and can be used on an outside scale for the benefit of the teacher in assessing students for learning that will be used in classrooms at the elementary school level.

\section{CONCLUSIONS}

The research product developed in the form of a linguistic intelligence assessment instrument received a positive impression from the teacher as the respondent that the teacher was very impressed with the product being developed because previously there were no products that could be used to measure linguistic intelligence and score setting and weighting and formulas made easy for teachers to understand and easy to apply. This positive response can also be seen when the trial process and the dissemination stage are carried out, namely the teacher does not experience many obstacles and difficulties in operating the developed assessment instrument, this indicates that the developed product is well received by the teacher as the subject who will use the linguistic intelligence assessment product developed by researchers so that the product can already be printed and can be used by a wider target.

\section{References}

Angelka, K., \& Goran, A. (2018). Learning Problems In Children With Mild Intellectual Disability. (IJCRSEE) International Journal of Cognitive Research in Science, Engineering and Education, 6(1), 31- 38. doi:10.5937/ijcrsee1801031K.

Azimah, R., \& Kurniaman, O. (2019). Implementasi Gerakan Literasi Sekolah dalam Pembelajaran di Kelas Tinggi. Jurnal PAJAR (Pendidikan dan Pengajaran), 3(4), 934-947. DOI: http://dx.doi.org/10.33578/pjr.v3i4.7567.

Chong, S. L. (2017). Many Languages, Whither Literacy? Understanding the Ontology of Reading in Linguistically-diverse Contexts. 3L: The Southeast 
Asian Journal of English Language Studies, 23(2), 1 - 13. http://doi.org/10.17576/3L-2017-2302-01.

Damaianti, V. S. (2017). Volitional Strategies Through Metacognitive Development In Fostering Reading Motivation. Indonesian Journal of Applied Linguistics, 7(2), pp. 274-284. doi: dx.doi.org/10.17509/ijal.v7i2.8130.

Douglas, D. (2018). Introduction: An Overview of Assessment and Teaching. Iranian Journal of Language Teaching Research 6(3), 1-7.

Gardner, H. (2003). Kecerdasan Majemuk (Terjemahan). Batam Centre: Interaksara.

Hermita, N., Hamid, R., Adiputra, M. J., \& Samsudin, A. (2017). Pembelajaran Berbasis Kecerdasan Jamak di SD Alternatif Pembelajaran Efektif. Yogyakarta: Deepublish.

Islam, R I, et al. (2019). Revisiting the Universality of Multiple Intelligences Theory in English Writing Classroom: Putting Theory Into Practice. ELS Journal on Interdisciplinary Studies in Humanities, 2 (1), 148-155.

Kurniaman, O., \& Noviana, E. (2016). Metode Membaca SAS (Struktural Analitik Sintetik) Dalam Meningkatkan Keterampilan Membaca Permulaan di Kelas I SDN 79 Pekanbaru. Primary: Jurnal Pendidikan Guru Sekolah Dasar, 5(2), 149- 157.

Kurniaman, O., Zufriady., Noviana, E., \& Afendi, N. (2018). Development of Teaching Materials for Reading Comprehension Skills Using the Graphic Organizer Media. Proceeding of the 2nd URICES, 2018, Pekanbaru, Indonesia. 385- 390.

Kurniaman, O., et al. (2018). Why Should Primary Teachers Develop Learning Material by Directed Reading Thinking Activity (DRTA) Strategy?: 4-D Model. Advanced Science Letters, 24(11), 8389-8391.

Kurniaman, O., \& Zufriady. (2019). The Effectiveness of Teaching Materials for Graphic Organizers in Reading in Elementary School Students. Journal of Educational Sciences, 3(1), 48-62. https://ejournal.unri.ac.id/index.php/JES.

Kafryawan, W., et al. (2018). The Influence of Intelligence on Students' Speaking Skills. ELS Journal on Interdisciplinary Studies in Humanities, 1(2), 145-152.

Kurniaman, O., \& SB. Sismulyasih, N. (2019. The Influence of The Big Book Media Has The Character of Conservation in Early Reading. ELS Journal on Interdisciplinary Studies in Humanities, 2 (1), 141-147.

Lazaer, D. (1995). Multiple Intelligence Approach to Assessment (Solving the Assessment Conundrum). Australia: Hawker Brownlow Education.

Magfirah, T. (2018). Students' reading and listening comprehension based on their learning styles. International Journal of Education, 10(2), 107-113. doi: http://dx.doi.org/. 
Mikhailova, O. B. (2018). Features Of Creativity And Innovation Development In Students At Secondary And High School. (IJCRSEE) International Journal of Cognitive Research in Science, Engineering and Education, 6(2), 11- 20. doi:10.5937/ijcrsee1802011M.

Sari, P., Palangngan, S. T., Mulyaningsih, E., Samritin, \& Rahman, F. (2019). Environmental expression using discourse analysis. IOP Conference Series: Earth and Environmental Science, 343(1). https://doi.org/10.1088/1755-1315/343/1/012149

Sugiyono. (2017). Cara Mudah Menyusun Skripsi, Tesis, dan Disertasi. Bandung: Alfabeta.

Susanti. (2018). The Use of Jigsaw II to Teach Reading to STMIK Students. MIMBAR PENDIDIKAN: Jurnal Indonesia untuk Kajian Pendidikan, 3(1), pp.85-96.

Thiagarajan. (1974). Instructional Development For Training Teachers of Exceptional Children: A Sourcebook. Washington D.C: National Centre or Improvement of Educational.

Yamashita, J., \& Shiotsu, T. (2015). Comprehension and Knowledge Components That Predict L2 Reading: A Latent-Trait Approach. Applied Linguistics, 1-26. doi:10.1093/applin/amu079.

Zulfah, \& Senam. (2018). Problem-Solving Ability Of Students With Disciplinary Literacy Instruction. (IJCRSEE) International Journal of Cognitive Research in Science, Engineering and Education, 6(2), 81- 88. doi:10.5937/ijcrsee1802081S. 